\title{
Determining the Effect of Planting Date and Land Preparation Method on Seedling Emergence, Forage Mass, and Forage Nutritive Value of Forage Brassica
}

\author{
Tayler D. Denman ${ }^{1, *(\mathbb{D})}$, Dennis W. Hancock ${ }^{2}$, S. Leanne Dillard ${ }^{3} \mathbb{D}$, Nicholas T. Basinger ${ }^{1}(\mathbb{D})$ and John D. Hale ${ }^{4}$ \\ 1 Department of Crop and Soil Sciences, University of Georgia, Athens, GA 30602, USA; \\ nicholas.basinger@uga.edu \\ 2 U.S. Dairy Forage Research Center, Madison, WI 53706, USA; dennis.hancock@usda.gov \\ 3 Department of Animal Sciences, Auburn University, Auburn, AL 36849, USA; dillasa@auburn.edu \\ 4 College of Agriculture and Environmental Science, University of Georgia, Athens, GA 30602, USA; \\ johale@uga.edu \\ * Correspondence: Tdd55849@uga.edu
}

\section{check for} updates

Citation: Denman, T.D.; Hancock, D.W.; Dillard, S.L.; Basinger, N.T.; Hale, J.D. Determining the Effect of Planting Date and Land Preparation Method on Seedling Emergence, Forage Mass, and Forage Nutritive Value of Forage Brassica. Agronomy 2021, 11, 1184. https://doi.org/ 10.3390/agronomy11061184

Academic Editors: Juan J. Villalba and Jennifer MacAdam

Received: 18 May 2021

Accepted: 8 June 2021

Published: 10 June 2021

Publisher's Note: MDPI stays neutral with regard to jurisdictional claims in published maps and institutional affiliations.

Copyright: (c) 2021 by the authors. Licensee MDPI, Basel, Switzerland. This article is an open access article distributed under the terms and conditions of the Creative Commons Attribution (CC BY) license (https:/ / creativecommons.org/licenses/by/ $4.0 /)$.

\begin{abstract}
Forage brassicas are used as a forage in monoculture and multispecies mixtures, yet research defining best management practices is limited. Two studies were conducted to evaluate the effects of land preparation method and planting date on establishment, forage mass, and quality of two Brassica species, 'Inspiration' canola (Brassica napus L.) and 'T-Raptor' hybrid turnip (B. rapa subsp. rapa $\times$ B. rapa L.). Each experiment was a randomized complete block design evaluating four land preparation methods: (conventional till (CT), no-till after burning (NB), no-till after mowing (NM), and notill without residue removal (NR)), and four planting dates: (1 September (S1), 15 September (S15), 1 October (O1), and 15 October (O15)). Significant differences were observed for the canola seedling emergence, but are not of biological significance. Hybrid turnip seedling emergence was the greatest for the CT treatment and consistently greater than NM and NR treatments. Forage mass in the canola study was greatest for the CT and NB. Hybrid turnip forage mass demonstrated similar trends to the canola. CT had the greatest mass and the NR and NM treatments tended to provide the lowest forage mass. Across both studies, earlier planting dates (S1 and S15) resulted in greater overall forage mass than the later planting dates (O1 and O15). Forage nutritive value overall was lower in earlier planted brassica; however, forage nutritive value was not reduced enough to negatively impact livestock.
\end{abstract}

Keywords: forage brassica; forage mass; forage quality; seedling emergence; planting date; land preparation method

\section{Introduction}

It is common practice in Georgia and other portions of the southeastern United States to utilize warm-season perennial grasses, such as bermudagrass (Cynodon dactylon) as a primary forage source due to their ability to produce significant mass from May through September. To expand the grazing season before bermudagrass growth begins (January through May), many producers in the southeastern United States utilize cool-season annual forages, such as cereal rye (Secale cereale) or annual ryegrass (Lolium multiflorum) interseeded into the dormant bermudagrass in early fall [1]. Unfortunately, few forage species are available to further extend the grazing season and fill the forage gap between the warmseason and cool-season transitional period in October through December.

Varieties of several Brassica spp., more specifically, canola (Brassica napus L.) and foragetype turnips (Brassica rapa L.) appear to offer promise as economical forage crops in the southeastern USA. Research has shown that brassicas have the potential to extend the grazing season by producing up to $4000 \mathrm{~kg} \mathrm{ha}^{-1}$ of forage mass during the transition period between warm-season and cool-season species [2]. Forage production at this time of 
year can help reduce the number of days in which conserved forage feeding is required [3], and potentially reduce input costs.

Research has shown that forage brassicas are also a high-quality forage with values adequate to sustain a lactating beef cow with observed crude protein (CP) of 200 to $250 \mathrm{~g} \mathrm{~kg}^{-1}$, neutral detergent fiber (NDF) and acid detergent fiber (ADF) approximately 19.8 and 16.8, respectively, and in vitro dry matter digestibility (IVDMD) ranging from 650 to $800 \mathrm{~g} \mathrm{~kg}^{-1}$ [4]. These unique characteristics can be beneficial at times when cow nutrient requirements are high during the fall calving season, or increasing average daily gains in stocker cattle [3] resulting in lower input costs, extended grazing seasons, and increasing profitability in forage-based livestock systems.

Though forage brassicas have proven to produce significant mass and nutritive value, there is no research on the effect of agronomic management practices such as planting date and land preparation method on the mass of canola or hybrid turnips, especially in the Southeastern United States. The objectives of these studies were to (1) evaluate the effects of land preparation practices and planting date on seedling emergence, forage mass, and quality of canola and forage turnips, and (2) develop best management practices for establishing brassica forage crops.

\section{Materials and Methods}

\subsection{Site Description}

Two experiments were conducted: The first experiment was conducted in the 2014-15 growing season using 'Inspiration' canola (Brassica napus L.) at two locations: the University of Georgia's Northwest Georgia Research and Education Center (GNREC) near Calhoun, GA on an Etowah loam soil (fine-loamy, siliceous, semiactive, thermic Typic Paledults) with two to six percent slopes and the J. Phil Campbell, Sr. Research and Education Center (JPCREC) in Watkinsville, GA on a moderately eroded Cecil sandy loam soil (fine, kaolinic, thermic, Typic Kanhapludults) with two to six percent slopes. The second study using hybrid turnip was conducted using and 'T-Raptor' hybrid turnip (B. rapa subsp. rapa $\times$ B. rapa L.) at the JPCREC in Watkinsville, GA also on a moderately eroded Cecil sandy loam soil (fine, kaolinic, thermic, Typic Kanhapludults) with two to six percent slopes for the 2016-2017 and 2017-2018 growing season. All study sites were limed and fertilized according to recommendations from the University of Georgia's Soil, Plant, and Water Laboratory.

\subsection{Weather}

Mean maximum and minimum temperatures followed an overall decreasing trend throughout the study in both locations for the canola study (Figure 1). The first two planting dates (S1 and S15) were exposed to greater minimum and maximum temperatures than the latter two planting dates (O1 and O15). Rainfall throughout the study was more consistent at the Calhoun location than at the Watkinsville location (Figure 1).

A similar trend was observed for the hybrid turnip study where minimum and maximum temperatures decreased throughout the study for both years (Figure 2). The first two planting dates (S1 and S15) were planted at temperatures higher than the latter two planting dates (O1 and O15; Figure 2) for both years. The 2016-2017 season received irrigation to ensure the establishment of the plots. 


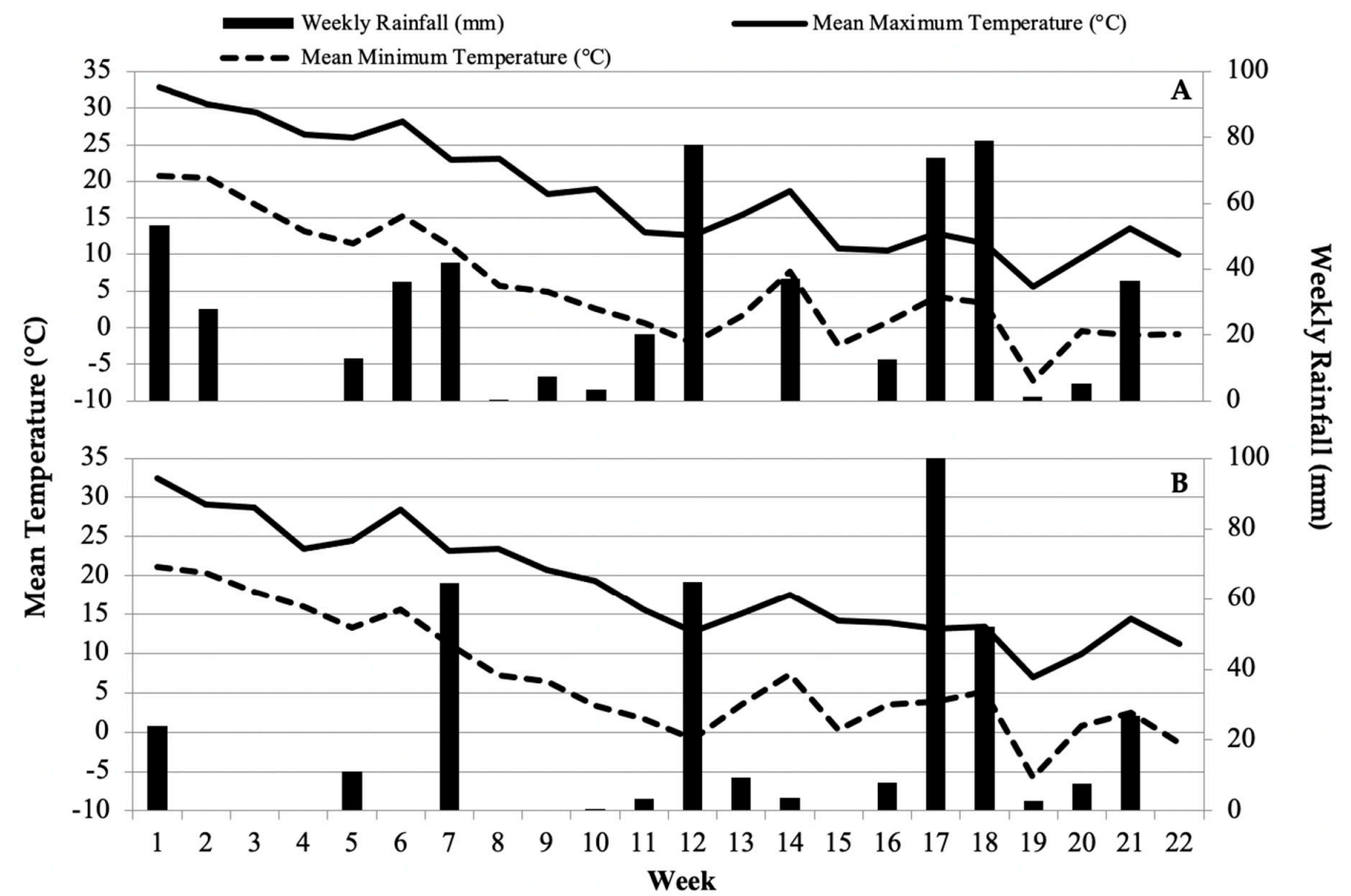

Figure 1. Mean maximum and minimum temperature for the Calhoun, GA (A) and Watkinsville, GA (B) 2014-15 growing season of the canola trial. Week 1 corresponds to the week of the 1 September (S1) planting date and week 22 corresponds to the end of January of each year.

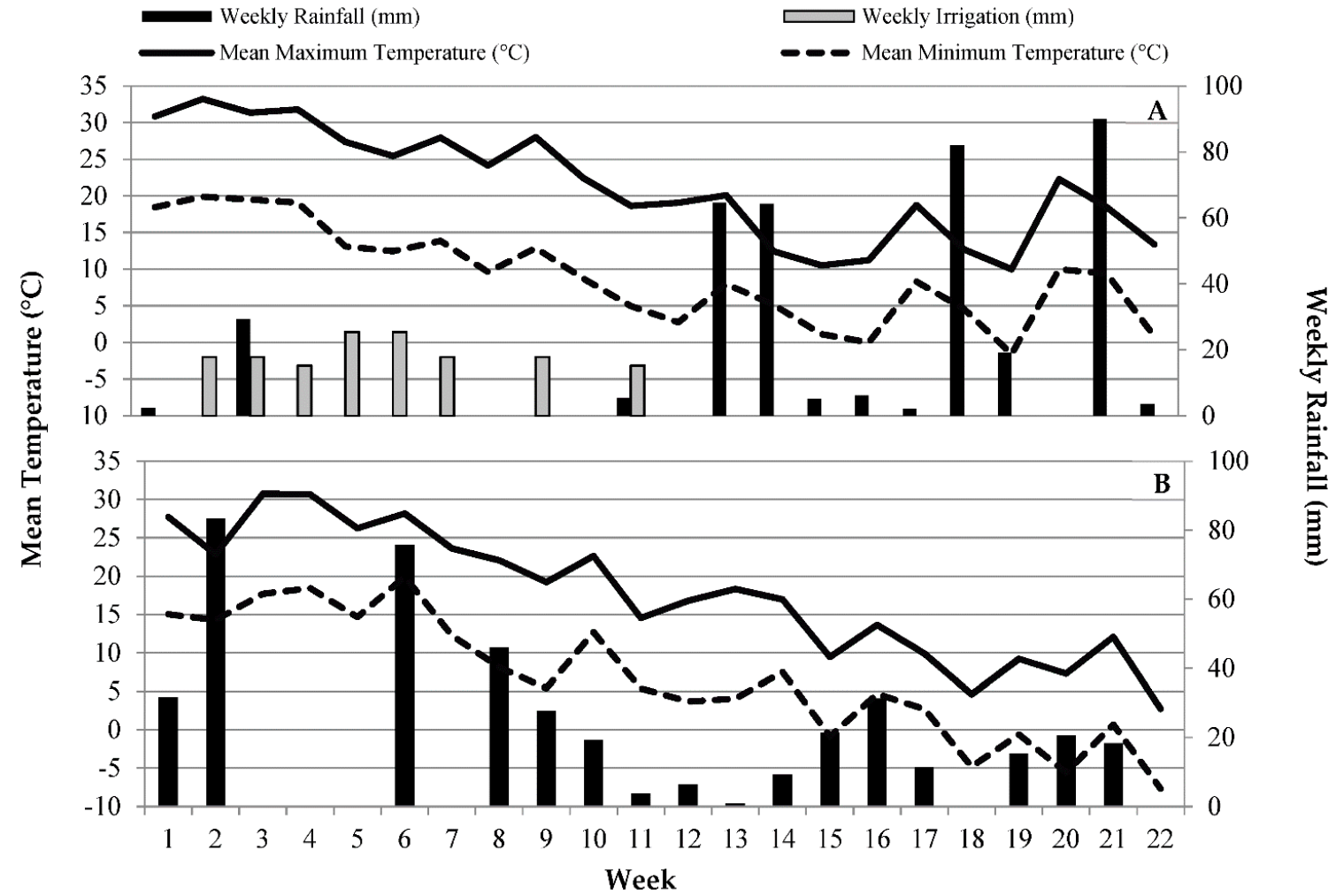

Figure 2. Mean maximum and minimum temperature for the 2016-2017 (A) and 2017-2018 (B) growing seasons of the hybrid brassica trial. Week 1 corresponds to the week of the 1 September planting date and week 22 corresponds to the end of January of each year. 


\subsection{Experimental Design}

Treatments were combinations of four land preparation methods (conventional tillage (CT), no-till after burning (NB), no- till after mowing (NM), and no-till with no residue removal (NR)) and four planting dates (1 September (S1), 15 September (S15), 1 October (O1), and 15 October (O15)) for a total of 16 treatment combinations per replication at each location. The experimental design for both studies was a randomized complete block design with a factorial arrangement of treatments in $1.6 \times 9.1 \mathrm{~m}$ plots and four replications.

\subsection{Land Preparation and Planting}

Two months before planting both the canola and hybrid turnip for this study, all land preparation treatments $(\mathrm{CT}, \mathrm{NB}, \mathrm{NM}$, and NR) within each planting date were cut using a Gravely (Gravely ${ }^{\odot}$, Brillion, WI, USA) forage plot harvester to a residue height of $5 \mathrm{~cm}$. One week before planting, glyphosate (Roundup Ultra ${ }^{\circledR}$ ) was applied at a rate of $1248 \mathrm{~g}$ a.i. $\mathrm{ha}^{-1}$ to the NB, NM and NR treatments. Approximately 3 days prior to planting, all land preparation method treatments were applied to their designated plots. Conventional till plots were tilled to a depth of $15 \mathrm{~cm}$ with a roto-tiller (Howard Rotavator HR15-75 USA) and cultipacked with a Brillion cultipacker (Model SS-60-03) to prepare the seedbed, while NB plots were physically burned, and NM plots were mowed using the forage plot harvester to a residue stubble height of $5 \mathrm{~cm}$. The NR plots had no residue removal except for that which occurred two months prior to planting.

After land preparation, plots in both studies were planted using a Great Plains no-till drill (3P605NT; Great Plains Manufacturing Inc; Salina, KS, USA) fitted with a Kincaid cone planter attachment (Kincaid; Haven, KS, USA). 'Inspiration' canola (Brassica napus L.) was planted at an adjusted rate of $4.48 \mathrm{~kg} \mathrm{ha}^{-1}$ (98\% pure live seed (PLS)), and 'T-Raptor' hybrid turnip (Brassica napus L. $\times$ Brassica rapa L.) was planted at a rate of $4.48 \mathrm{~kg} \mathrm{PLS}^{-1}$ $\left(90 \%\right.$ PLS adjusted rate of $\left.4.98 \mathrm{~kg} \mathrm{ha}^{-1}\right)$. Both studies were planted on a $19.1 \mathrm{~cm}$ row spacing and planted at a depth of $0.6 \mathrm{~cm}$.

\subsection{Pest Control and Irrigation}

For the canola study, a tank-mixture of clomazone $\left(\right.$ Command $\left.3 \mathrm{ME}^{\circledR}\right)$ at a rate of $91.9 \mathrm{~g}$ a.i. $\mathrm{ha}^{-1}$ and S-metolachlor (Dual Magnum ${ }^{\circledR}$ ) at a rate of $234 \mathrm{~g}$ a.i. ha ${ }^{-1}$ was applied as a pre-emergent herbicide to the plots one week after planting. In addition, the insecticide zeta-cypermethrin (Mustang Maxx ${ }^{\circledR}$ ) was applied at a rate of $27.8 \mathrm{~g}$ a.i. ha ${ }^{-1}$ to the Watkinsville location on 24 September and both the Calhoun and Watkinsville location received a fungicide application of prothioconazole (Proline $480 \mathrm{SC}^{\circledR}$ ) at a rate of $1596 \mathrm{~g} \mathrm{ha}^{-1}$ on 12 March and 11 March, respectively, to prophylactically control disease. All plots were fertilized at a rate of $56 \mathrm{~kg} \mathrm{~N} \mathrm{ha}^{-1} 14$ days after planting and again on 15 March. The canola trial did not receive supplemental irrigation at either location. The hybrid turnip study received an identical treatment of fertilizer to the canola study and were fertilized at a rate of $56 \mathrm{~kg} \mathrm{~N}^{-1} 14 \mathrm{DAP}$ and again at $100 \mathrm{DAP}$.

For the hybrid turnip study, in 2016-2017 the plot area was over-head irrigated with a solid-set irrigation gun to supply a minimum of $17 \mathrm{~mm}$ week $^{-1}$ in which naturally occurring rainfall did not exceed this amount. Temperature and rainfall data were collected through the University of Georgia Weather Network's [5] weather stations located at the J. Phil Campbell Sr. Research and Education Center in Watkinsville, GA. No irrigation was needed during the 2017-2018 season due to timely rainfall resulting in adequate soil moisture after planting. Temperature and rainfall data for the canola study were collected through the University of Georgia Weather Network's [5] weather stations located at the Northwest Georgia Research and Education Center in Rome, GA.

\subsection{Sampling}

Seedling emergence for both the canola and hybrid turnip study were evaluated at 14 DAP for each year that the studies were conducted. Emergence was determined by counting emerged seedlings over three randomly selected $1.8 \mathrm{~m}$ long sections of a planting 
row. Seedlings were counted using a $30 \mathrm{~cm}$ quadrat subdivided into $9 \mathrm{~cm}$ transects. Seedlings were counted when an emerged seedling (breaking soil surface) aligned with $9 \mathrm{~cm}$ transect points along the designated section of the planting row.

Forage mass was measured from the canola study at 45 and 90 DAP and from the hybrid turnip study at 30,45,60, and 90 DAP. Both the canola and hybrid turnip studies were harvested by randomly placing a $0.9 \mathrm{~m}^{2}$ quadrat within the plot boundaries and harvesting all brassica mass within the quadrat to bare ground. Each quadrat area that was sampled was then flagged to prevent overlapping of sampling areas for future harvest dates and no sampling points were within $0.5 \mathrm{~m}$ of a previously sampled point. A total of three quadrat harvests were obtained from each plot at each designated harvest timing. Harvested mass was placed in a forced-air drying oven at $60^{\circ} \mathrm{C}$ until the final weight remained unchanged. The dry weight was then used to calculate forage mass in $\mathrm{kg} \mathrm{DM} \mathrm{ha}^{-1}$.

Data on forage quality were obtained only for the hybrid turnip study. The samples harvested at 60 and 90 DAP were ground using a Wiley ${ }^{\circledR}$ Mill (Thomas Scientific, Swedesboro, NJ) until the sample passed through a $2 \mathrm{~mm}$ sieve. Samples were then further processed using a Cyclotec 1093 Sample Mill (Foss, Hillerod, Denmark) so that the samples would pass through a $1 \mathrm{~mm}$ sieve. Processed samples were submitted to the University of Georgia's Feed and Environmental Water Lab to determine CP, NDF, ADF, lignin, total digestible nutrients (TDN), and digestible neutral detergent fiber at $30 \mathrm{~h}$ (dNDF30) using near infrared reflectance spectroscopy (FOSS 6500, FOSS NIRS system Inc., Laurel, Maryland). Samples were also analyzed for nitrate $\left(\mathrm{NO}_{3}-\mathrm{N}\right)$ concentration using the nitration of salicylic acid method (Cataldo et al., 1975) and absorbance measured using a spectrophotometer (Shimadzu UV-2450, Shimadzu Scientific Instruments (SSI), Kyoto, Japan).

\subsection{Statistical Analysis}

Data for both studies were analyzed using a generalized linear mixed model procedure in JMP Pro version 13.2.1 (SAS Institute, Inc., Cary, NC). Location (canola trial) or year (hybrid turnip trial) were evaluated as random effects and planting date, land preparation method, and replication as random effects. Effects were evaluated using ANOVA. If interactions were significant, response variables were assessed accordingly. Mean separation was performed using Fishers-protected least squares difference (LSD). Treatment effects and interactions were considered significant at $\alpha=0.05$. Factors evaluated included seedling count, forage mass at 45 and 90 DAP for the canola study, and 30, 45, 60, and 90 DAP for the hybrid turnip study. Nutritive value of the CT treatments of the S1 and O1 planting dates were evaluated for the hybrid turnip study. Components of nutritive value evaluated included $\mathrm{CP}, \mathrm{TDN}, \mathrm{dNDF}$, and lignin. A test for homogeneity of variance was conducted in which assumptions for homogeneity were not met for seedling emergence of the turnip study. ANOVA was conducted on $\log _{10}$ transformed data to satisfy homogeneity of variance. Non-transformed results are presented below (Figure 3). 


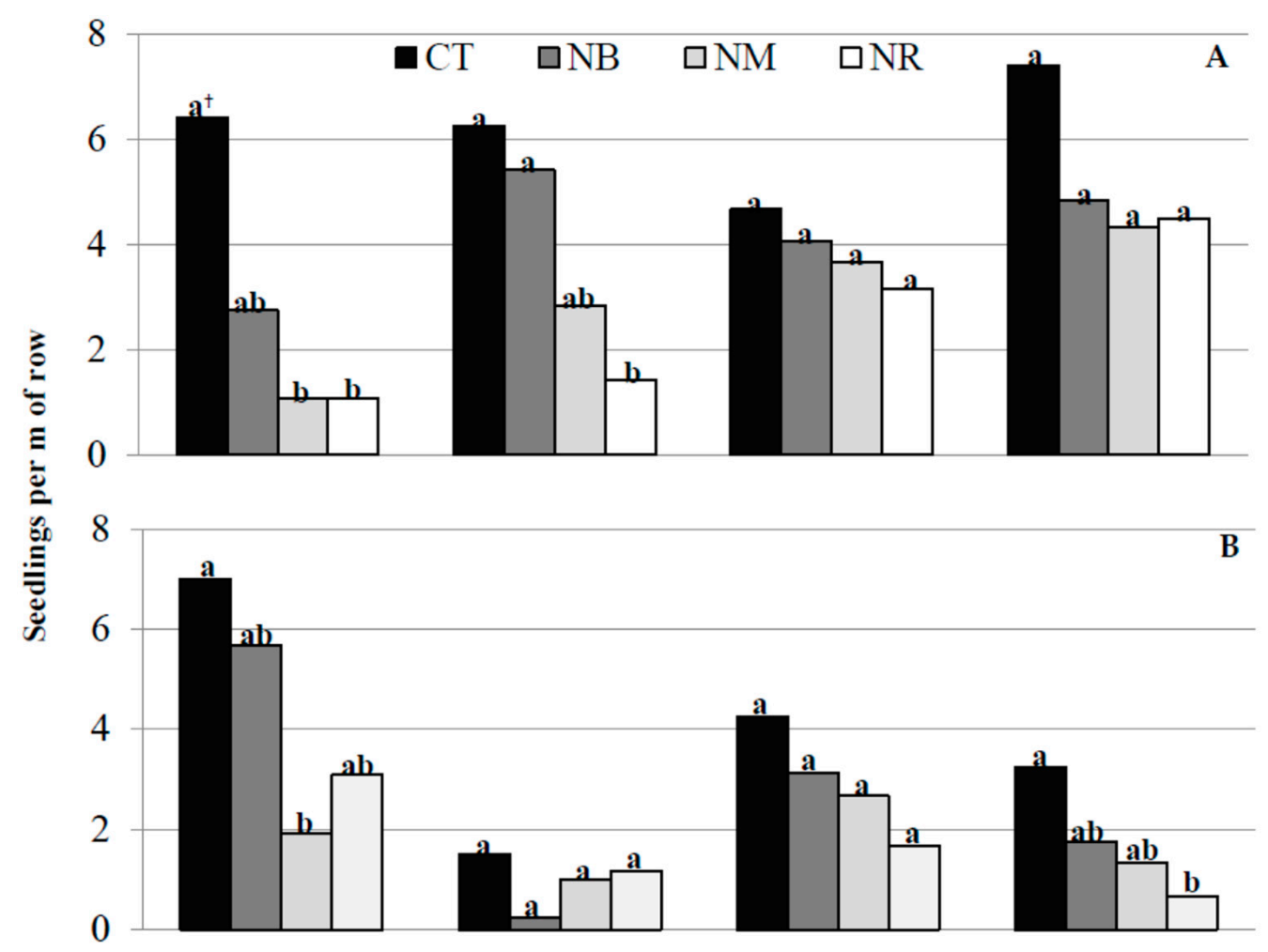

Planting Date

Figure 3. ${ }^{\dagger}$ Means within the same planting date sharing the same letters but are not statistically different according to Fisher's protected LSD $(p<0.05)$. Seedlings per $\mathrm{m}$ of row of the hybrid turnip 14 days after planting for the 1 September (S1), 15 September (S15), 1 October (O1), and 15 October (O15) planting dates for each land preparation method: conventional tillage (CT), NB, NM, and NR. For the 2016-2017 growing season (A) and the 2017-2018 growing season (B).

\section{Results and Discussion}

\subsection{Seedling Emergence}

For the canola study, seedling counts 14 DAP differed $(p<0.002)$ among the combinations of planting date, land preparation, and location, but there were no discernable trends and the differences did not appear to be of biological significance. Seedling count data for the canola study are presented for each planting date, land preparation method, and location (Appendix A).

For the hybrid turnip study, interactions between year, land preparation method, and planting date were observed $(p=0.043)$.

In the 2016-2017 growing season, the NM and NR treatments for both the S1 and S15 planting dates had decreased seedling emergence when compared to the CT treatment. At the later planting dates (O1 and $\mathrm{O} 15)$ all four land preparation methods were not significant from one another.

In the 2017-2018 growing season, the CT and NB treatments were not significantly different in number of seedlings per row, and both produced the greatest number of seedlings per $\mathrm{m}$ row compared to the NR and NM treatments. For all land preparation treatments, the S15 and O1 planting dates were not different. It is important to note that the S15 planting date in the 2017-2018 growing season was planted shortly after Hurricane Irma, followed by several weeks of drought (Figure 2). The authors predict the low seedling emergence for this planting date was due to seedlings germinating and emerging and subsequently senescing as a result of moisture deficit. 
The CT treatment had the greatest germination for all planting dates for both the 2016-2017 and 2017-2018 growing seasons. In addition, the NB treatment was similar to the CT treatment at all planting dates thus indicating that the CT and NB treatments provided comparable seedling emergence across all planting dates. Overall, the 2016-2017 growing season seedling emergence increased as the planting date was delayed whereas the 2017-2018 growing season shows a decrease in overall seedling emergence as the planting date was delayed. These results are comparable to [6,7], where cooler temperatures resulted in delayed seedling emergence and poor establishment. The observed trends can be explained by weather conditions for each year (Figure 2). The 2016-2017 growing season had greater rainfall during the later (O1 and O15) planting dates than the earlier (S1 and S15) planting dates. For the 2017-2018 growing season, a larger amount of rainfall was observed during the earlier (S1) planting date than the later (O1 and O15) planting dates.

Overall, seedling emergence may be more affected by available moisture at the time of planting and shortly thereafter rather than planting date or land preparation method however, as the plants begin to grow, other factors similar to planting date with respect to temperature and land preparation method do affect overall forage mass.

\subsection{Forage Mass}

For the canola study, interactions between location, planting date, and land preparation method $(p<0.001)$ were noted. Therefore, forage mass at 45 and 90 DAP is presented by location and planting date (Table 1). Forage mass was substantially greater in Calhoun than in Watkinsville, thereby muting the treatment differences at the latter location. Therefore, the data are presented for each planting date and land preparation method at each location at 45 and 90 DAP (Table 1 ).

Differences were only observed within the S1 and O15 planting date in Calhoun and the S1 planting date in Watkinsville for the 45 DAP forage mass measurements and the S1 and $\mathrm{O} 15$ planting dates in Calhoun and the S15 and O15 planting dates in Watkinsville for the 90 DAP forage mass assessments. When differences occurred, the CT or NB treatments had the greatest forage mass, and the NR treatment had the least, except for the O15 planting date at the Calhoun location. Otherwise, a discernable trend for the effect of planting date and land preparation method was not detected. This is likely because there are several interacting factors that affect forage mass other than just planting date and land preparation method.

The S1 and S15 planting dates at the Calhoun location (2183 and $2152 \mathrm{~kg} \mathrm{DM} \mathrm{ha}^{-1}$ at $45 \mathrm{DAP}$, respectively and 5545 and $3451 \mathrm{~kg} \mathrm{DM} \mathrm{ha}^{-1}$ at $90 \mathrm{DAP}$, respectively) produced greater mass than the $\mathrm{O} 1$ and $\mathrm{O} 15$ planting dates $\left(491\right.$ and $18 \mathrm{~kg} \mathrm{DM} \mathrm{ha}^{-1}$ at $45 \mathrm{DAP}$, respectively and 1491 and $13 \mathrm{~kg} \mathrm{DM} \mathrm{ha}^{-1}$ at $90 \mathrm{DAP}$, respectively, Table 1) for the CT treatment. This is consistent with the results of [8], which showed that earlier planting dates and warmer weather have a positive impact on forage mass (Figure 1 and Table 1). However, planting dates at the Watkinsville location did not follow this trend. One possible reason for the lower forage mass for the S1 and S15 planting dates at the Watkinsville location is that location had a longer period in which no rainfall occurred during that time when compared to the Calhoun location. These results are consistent with [8], which found forage brassica mass was greater in years when rainfall accumulation averaged $120 \mathrm{~cm}$ annually.

For the hybrid turnip study, an interaction of year and planting date was observed at $30 \mathrm{DAP}(p<0.001)$ and interactions of year, planting date, and land preparation method were observed at $45(p=0.040), 60(p=0.003)$ and 90 DAP $(p<0.001)$. Therefore, data are presented for each year and planting date (Table 2).

Similar to the results in the canola study, the CT treatment tended $(p<0.05)$ to provide the highest forage mass at 30,45, 60, and 90 DAP for all planting dates in both years whenever significant differences were observed. The CT and NB treatments had forage mass measurements that were not different from each other, except for the $\mathrm{O} 15$ planting date in 2017-2018 where CT was higher than the NB treatment at 30, 45, and 60 DAP. 
Moreover, the NR treatments tended $(p<0.05)$ to provide the lowest forage mass at 30, 45, 60 , and $90 \mathrm{DAP}$ for each planting date and year whenever significant differences occurred, and the NR treatments were not superior to the NM treatments.

Table 1. Forage mass of canola at each land preparation method: conventional till (CT), no-till burn (NB), no-till mow (NM), and no-till with residue (NR) land preparation methods on four planting dates: 1 September, 15 September, 1 October, and 15 October at the Calhoun, GA and Watkinsville, GA locations for canola grown in 2014-2015.

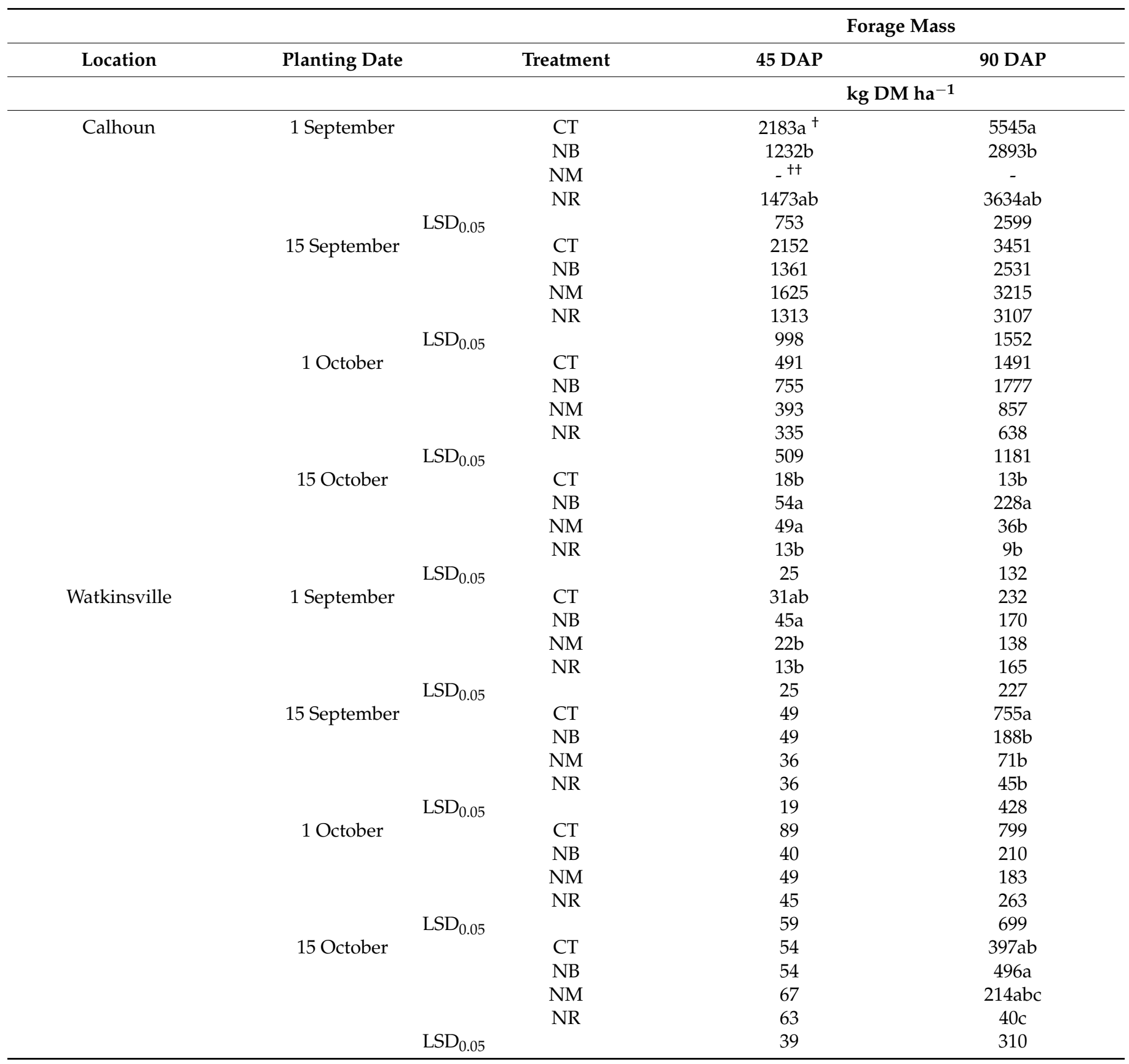

${ }^{\dagger}$ Means within a planting date and land preparation method combination sharing the same letters that are not statistically different according to Fisher's protected LSD $(p<0.05) .{ }^{++}$Planting error resulted in failed establishment. 
Table 2. Forage mass of hybrid turnip at each land preparation method: conventional till (CT), no-till burn (NB), no-till mow (NM), and no till with residue (NR) land preparation methods on four planting dates: 1 September, 15 September, 1 October, and 15 October in the 2016-2017 and 2017-2018 growing season in the hybrid turnip trial.

\begin{tabular}{|c|c|c|c|c|c|c|}
\hline \multirow[b]{2}{*}{ Year } & \multirow[b]{2}{*}{ Planting Date } & \multicolumn{5}{|c|}{ Forage Mass } \\
\hline & & Treatment & 30 DAP & 45 DAP & 60 DAP & 90 DAP \\
\hline & & & \multicolumn{4}{|c|}{ kg DM ha ${ }^{-1}$} \\
\hline \multirow[t]{20}{*}{2016 - } & 1 September & $\mathrm{CT}$ & $116 \mathrm{a}^{+}$ & $1360 a$ & $2173 a$ & $4669 a$ \\
\hline & & NB & $80 \mathrm{ab}$ & $903 a b$ & $1163 \mathrm{ab}$ & $2147 \mathrm{ab}$ \\
\hline & & NM & $36 b$ & $80 \mathrm{bc}$ & $116 b$ & $116 b$ \\
\hline & & NR & $18 b$ & $18 \mathrm{c}$ & $27 \mathrm{~b}$ & $27 \mathrm{~b}$ \\
\hline & & & 62 & 873 & 1371 & 2851 \\
\hline & 15 September & $\mathrm{CT}$ & $483 a$ & $1091 \mathrm{a}$ & $1771 \mathrm{ab}$ & $2254 \mathrm{ab}$ \\
\hline & & NB & $358 \mathrm{ab}$ & $1154 a$ & $2889 a$ & $4937 a$ \\
\hline & & NM & $63 b c$ & $89 b$ & $161 b c$ & $868 b$ \\
\hline & & NR & $27 \mathrm{c}$ & $36 b$ & $18 c$ & $18 b$ \\
\hline & & & 298 & 746 & 1667 & 3297 \\
\hline & 1 October & $\mathrm{CT}$ & 98 & $599 a$ & $1324 a$ & $1431 \mathrm{a}$ \\
\hline & & NB & 98 & $510 \mathrm{ab}$ & $1351 \mathrm{a}$ & $1324 a$ \\
\hline & & NM & 89 & $179 b c$ & $662 \mathrm{ab}$ & $1261 \mathrm{a}$ \\
\hline & & NR & 72 & $63 c$ & $116 b$ & $161 b$ \\
\hline & & & 27 & 379 & 952 & 1075 \\
\hline & 15 October & $\mathrm{CT}$ & 134 & $519 a$ & $859 a$ & $1610 a$ \\
\hline & & NB & 89 & $358 \mathrm{ab}$ & $555 \mathrm{ab}$ & $1324 \mathrm{ab}$ \\
\hline & & NM & 80 & $107 \mathrm{bc}$ & $116 b$ & $80 b$ \\
\hline & & NR & 89 & $54 c$ & $72 b$ & $9 b$ \\
\hline & & & 48 & 292 & 542 & 1379 \\
\hline \multirow[t]{20}{*}{2017 - } & 1 September & $\mathrm{CT}$ & 533 & $1297 a$ & $3381 a$ & $4481 \mathrm{a}$ \\
\hline & & NB & 883 & 742ab & 1968ab & $2379 a$ \\
\hline & & NM & 31 & $546 \mathrm{~b}$ & $751 b$ & $3068 \mathrm{a}$ \\
\hline & & NR & 54 & $805 \mathrm{ab}$ & $1816 \mathrm{ab}$ & $2862 a$ \\
\hline & & & 861 & 698 & 1714 & 2807 \\
\hline & 15 September & $\mathrm{CT}$ & 73 & 438 & 689 & 778 \\
\hline & & NB & 1 & 1 & 0 & 0 \\
\hline & & NM & 37 & 153 & 64 & 946 \\
\hline & & NR & 2 & 57 & 1 & 437 \\
\hline & & & 90 & 530 & 823 & 1222 \\
\hline & 1 October & $\mathrm{CT}$ & $35 \mathrm{ab}$ & $229 \mathrm{ab}$ & $700 \mathrm{a}$ & $1714 a$ \\
\hline & & NB & $68 a$ & $298 \mathrm{a}$ & $433 a b$ & $814 \mathrm{ab}$ \\
\hline & & NM & $11 \mathrm{ab}$ & $23 b$ & $119 b$ & $254 b$ \\
\hline & & NR & $4 b$ & $25 \mathrm{ab}$ & $177 \mathrm{~b}$ & $288 b$ \\
\hline & & & 61 & 212 & 463 & 1125 \\
\hline & 15 October & $\mathrm{CT}$ & $34 \mathrm{a}$ & $196 a$ & $378 a$ & $270 \mathrm{a}$ \\
\hline & & NB & $8 b$ & $31 b$ & $126 b$ & $150 \mathrm{ab}$ \\
\hline & & NM & $5 b$ & $26 b$ & $103 b$ & $128 \mathrm{ab}$ \\
\hline & & NR & $0 \mathrm{~b}$ & $14 b$ & $25 b$ & ob \\
\hline & & & 22 & 111 & 246 & 244 \\
\hline
\end{tabular}

† Similar letters within the same column are not statistically different according to Fisher's protected LSD $(p<0.05)$.

The S1 and S15 planting dates in the 2016-2017 season (e.g., 4669 and $4937 \mathrm{~kg} \mathrm{DM} \mathrm{ha}^{-1}$ at $90 \mathrm{DAP}$, respectively) performed better than the $\mathrm{O} 1$ and $\mathrm{O} 15$ planting dates (1431 and $1610 \mathrm{~kg} \mathrm{DM} \mathrm{ha}^{-1}$ at 90 DAP, respectively, Table 2). Similar results may have occurred in the 2017-2018 season had it not been for heavy rainfall from the remnants of a hurricane immediately following the S15 planting date. These results are consistent with those of [8], where October sown brassica planted in Southern Florida produced higher forage mass (4040 kg DM ha ${ }^{-1}$ ) when exposed to warmer growing conditions than the November and January planting dates (2820 and $1550 \mathrm{~kg} \mathrm{DM} \mathrm{ha}^{-1}$ respectively) and the autumn-grown brassica forage mass (2839 to $4046 \mathrm{~kg} \mathrm{DM} \mathrm{ha}^{-1}$ ) reported by [9]. 
Results obtained from both the canola and hybrid turnip trials indicate that earlier planting dates (S1 and S15) result in higher overall forage mass when compared to later planting dates (O1 and $\mathrm{O} 15)$. These results are comparable to other studies conducted by $[8,9]$, which found that warmer planting dates produced greater forage mass.

\subsection{Forage Nutritive Value}

Forage nutritive value was assessed only for the hybrid turnip study. Only the CT treatment in the $\mathrm{S} 1$ and $\mathrm{O} 1$ planting dates provided sufficient quantities of sample for a complete set of plots and treatments across both years to enable a comparison of forage nutritive value. $\mathrm{CP}$ concentrations were affected by year $(p=0.017)$ and planting date $(p=0.048)$, but there were no interactions at $60 \mathrm{DAP}$. There was an interaction of year and planting date at $90 \mathrm{DAP}$.

Mean CP concentrations were higher in 2016-2017 than in 2017-2018 at 60 DAP (254 and $225 \mathrm{~g} \mathrm{~kg}^{-1}$, respectively) when pooled across both the $\mathrm{S} 1$ and $\mathrm{O} 1$ planting dates. When pooled across years, mean CP concentrations were observed to be greater for the $\mathrm{S} 1$ than the O1 planting dates at $60 \mathrm{DAP}$ (228 and $253 \mathrm{~g} \mathrm{~kg}^{-1}$, respectively). At $90 \mathrm{DAP}$, there was no difference between CP concentrations of the S1 and O1 planting dates in 2016-2017 (173 and $207 \mathrm{~g} \mathrm{~kg}^{-1}$, respectively), while the S1 planting date had lower CP concentrations than the O1 planting date (151 and $227 \mathrm{~g} \mathrm{~kg}^{-1}$, respectively) in 2017-2018. These results are similar to those observed by [8], in which they also observed an increase in CP concentrations as planting date was delayed. [10] observed CP concentrations slightly lower $\left(198 \mathrm{~g} \mathrm{~kg}^{-1}\right)$ than those observed in this study, though they also observed a similar trend in that the earlier planting dates tended to have lower $\mathrm{CP}$ concentrations than the later planting dates. Both [11] and [8] observed an inverse relationship between forage mass and CP concentrations. This inverse relationship was also observed in our experiment in that the later planting date $(\mathrm{O} 1)$ had greater $\mathrm{CP}$ concentrations yet lower forage mass than the S1 planting date that had higher forage mass but lower $\mathrm{CP}$ concentrations. Crude protein concentrations also decreased between 60 and 90 DAP. The decrease in CP may be due to the result of increasing plant maturity, indicated by an increase in lignin concentrations that were observed to be higher in the S1 planting date than the $\mathrm{O} 1$ planting date. The $\mathrm{CP}$ concentrations reported here are comparable to those observed by Westwood et al. (2012) for forage type turnips $\left(226 \mathrm{~g} \mathrm{~kg}^{-1}\right)$. Observed CP concentrations in the current study and those reported by [12] are comparable to bud stage alfalfa (220 to $260 \mathrm{~g} \mathrm{~kg}^{-1} \mathrm{CP}$ ). These concentrations are more than sufficient to support a lactating beef cow (110 to $130 \mathrm{~g} \mathrm{~kg}^{-1}$ $\mathrm{CP}$ concentrations; [13]), though the proportion of this protein that is rumen-degradable, rumen-undegradable, and indigestible will require further research.

There were no differences in TDN concentrations across year or planting date at $60 \mathrm{DAP}$, though the S1 planting date had lower $(p<0.004)$ TDN values than the $\mathrm{O} 1$ planting date (740 and $786 \mathrm{~g} \mathrm{~kg}^{-1}$ respectively) at 90DAP. The TDN values observed in the current study are higher than bud stage alfalfa ( 640 to $670 \mathrm{~g}^{\mathrm{TDN} \mathrm{kg}}{ }^{-1}$ ) or an early flowering red clover ( 640 to $670 \mathrm{~g} \mathrm{TDN} \mathrm{kg}^{-1}$ ) and high enough to easily meet requirements for a growing beef steer and a lactating beef cow (680 and $600 \mathrm{~g} \mathrm{~kg}^{-1}$, respectively [13]).

For dNDF30, the effect of planting date differed by year at both 60 and 90 DAP $(p<0.008$ and $p<0.004$ respectively). In 2016-2017, there was no difference for dNDF30 values across planting dates (114 and $122 \mathrm{~g}$ dNDF30 $\mathrm{kg}^{-1}$, respectively) at $60 \mathrm{DAP}$. In contrast, the dNDF30 values year were greater in the S1 planting date than the $\mathrm{O} 1$ planting date (152 and $123 \mathrm{~g} \mathrm{~kg}^{-1}$ respectively) at $60 \mathrm{DAP}$ in 2017-2018. At $90 \mathrm{DAP}$, the S1 planting date had higher dNDF30 values than the O1 planting date in both years (156 vs. $136 \mathrm{~g} \mathrm{~kg}^{-1}$ for S1 and O1, respectively in 2016-17 and 187 vs $125 \mathrm{~g} \mathrm{~kg}^{-1}$ for S1 and O1, respectively in 2017-2018).

No statistical significance in lignin concentrations was observed across year or planting date at $60 \mathrm{DAP}$, though there was a planting date effect $(p=0.003)$ at $90 \mathrm{DAP}$ where the S1 planting date had higher lignin concentration than the $\mathrm{O} 1$ planting date $\left(710\right.$ and $540 \mathrm{~g} \mathrm{~kg}^{-1}$ respectively); however, the overall low lignin concentrations across both planting dates at 
90 DAP would not be of biological significance because the lignin concentration would not be high enough to be detrimental to the forage quality and overall rumen function.

\section{Conclusions}

In 2016-2017, seedling emergence increased as planting date was delayed however, contradicting information was obtained in the 2017-2018 year. These results may be due to changes in amount of rainfall for each of the growing seasons, indicating that rainfall may play a more important role in seedling emergence. Results suggest that forage mass is affected by seedling emergence and that sufficient rainfall or supplemental irrigation is needed to ensure adequate seedling emergence. Planting date and land preparation methods do have an impact on forage mass and the nutritive value of forage brassica. Land preparation method also has a significant effect on mass. In both trials, the CT or NB plots produced the greatest forage mass compared to NM and NR plots. Delayed planting also affects forage nutritive value. When comparing $\mathrm{S} 1$ to $\mathrm{O} 1$ planting dates, $\mathrm{CP}$ concentration and TDN values increased whereas dNDF30 values decreased. Overall, CP and TDN values of brassica are more than sufficient to sustain livestock with high maintenance requirements such as lactating beef cattle [1,13].

In conclusion, planting brassica early (S1 and S15) into minimal residue (CT and NB) will produce the greatest forage mass in the Southeastern United States. Forage nutritive value is reduced in earlier planted brassica. However, forage nutritive value is not reduced enough to negatively impact livestock with high maintenance requirements. It is important to note that the low fiber and lignin concentration may increase passage rate in ruminant animals and additional research needs to be conducted to evaluate the ruminant interaction when including forage brassicas as part of a diet.

Author Contributions: Conceptualization, D.W.H. and S.L.D.; data curation, T.D.D., S.L.D. and J.D.H.; formal analysis, T.D.D. and D.W.H.; funding acquisition, D.W.H. and S.L.D.; investigation, T.D.D., D.W.H., S.L.D. and J.D.H.; methodology, D.W.H. and S.L.D.; project administration, D.W.H. and J.D.H.; resources, J.D.H.; supervision, D.W.H., S.L.D. and J.D.H.; validation, T.D.D., N.T.B., and J.D.H.; visualization, T.D.D.; writing-original draft, T.D.D.; writing-review \& editing, D.W.H., S.L.D., N.T.B. and J.D.H. All authors have read and agreed to the published version of the manuscript.

Funding: This research was funded by USDA-NIFA. Grant Number: GEO2013-05091 and the Georgia Agricultural Commodity Commission for Beef.

Data Availability Statement: Publicly available datasets of temperature and rainfall were evaluated in this study. This data can be found at: http:/ / weather.uga.edu/?variable=HI\&site=WATUSDA, accessed on 15 May 2021.

Acknowledgments: The authors would like to thank the J. Phil Campbell Sr. Research and Education Center in Watkinsville, GA, and the Northwest Research and Education Center in Calhoun, GA who provided locations for this research to be conducted. Efforts from all three entities along with assistance from J.D.H., Hunter Knapp, Sarah Spradlin, Sam Ingram, and Deidre Harmon enabled this work to be conducted.

Conflicts of Interest: The authors declare no conflict of interest.

\section{Appendix A}

Table A1. Seedling count 14 days after planting for each combination of location, land preparation method, and planting date compared in the canola trial.

\begin{tabular}{cccccc}
\hline \multirow{2}{*}{ Location } & \multirow{2}{*}{ Land Preparation Treatment } & \multicolumn{3}{c}{ Planting Date } \\
\cline { 3 - 5 } & & 1 September & 15 September & 1 October & 15 October \\
\hline Calhoun & $\mathrm{CT}$ & $10.0 \mathrm{a}$ & \multicolumn{2}{c}{ Seedlings per m row } \\
& $\mathrm{NB}$ & $6.6 \mathrm{~b}$ & 7.6 & $7.3 \mathrm{ab}$ & $6 \mathrm{ab}$ \\
& & 8.3 & $9.9 \mathrm{a}$ & $7.3 \mathrm{a}$ \\
\hline
\end{tabular}


Table A1. Cont.

\begin{tabular}{|c|c|c|c|c|c|}
\hline \multirow{2}{*}{ Location } & \multirow{2}{*}{ Land Preparation Treatment } & \multicolumn{4}{|c|}{ Planting Date } \\
\hline & & 1 September & 15 September & 1 October & 15 October \\
\hline \multirow{9}{*}{ Watkinsville } & NM & $-{ }^{+\dagger}$ & 7.3 & $6.3 \mathrm{~b}$ & $6.5 \mathrm{ab}$ \\
\hline & NR & $6.4 \mathrm{~b}$ & 5.8 & $7.7 \mathrm{ab}$ & $4.9 \mathrm{~b}$ \\
\hline & $\mathrm{LSD}_{0.05}$ & 2.73 & 2.81 & 3.42 & 2.23 \\
\hline & & & & & \\
\hline & $\mathrm{CT}$ & 9.3 & $6.0 \mathrm{ab}$ & $7.1 \mathrm{a}$ & 7.0 \\
\hline & NB & 10.9 & $6.2 \mathrm{a}$ & $3.8 \mathrm{~b}$ & 7.4 \\
\hline & NM & 11.6 & $4.4 \mathrm{ab}$ & $5.7 \mathrm{ab}$ & 6.7 \\
\hline & NR & 11.4 & $3.3 \mathrm{~b}$ & $7.9 \mathrm{a}$ & 8.4 \\
\hline & $\mathrm{LSD}_{0.05}$ & 3.80 & 2.72 & 2.87 & 2.11 \\
\hline
\end{tabular}

${ }^{+}$Means within a planting date and land preparation method combination sharing the same letters that are not statistically different according to Fisher's protected LSD $(p<0.05) .{ }^{++}$Error at planting resulted in this treatment combination not being established.

\section{References}

1. Ball, D.M.; Hoveland, C.S.; Lacefield, G.D. Southern Forages, 5th ed.; International Plant Nutrition Institute: Norcross, GA, USA, 2015.

2. Lemus, R.; White, J. Forage Brassicas for Winter Grazing Systems; Publication 2845; Mississippi State University Extension Services: Starkville, MS, USA, 2014.

3. Stewart, L.R.; Lacy, C.R.; Hancock, D.W.; Harris, G.H.; Ellis, R.W.; Silcox, R.E. Cutting Costs, Not Corners: Managing Cattle in Tough Times; Bulletin 1373; University of Georgia Cooperative Extension: Athens, GA, USA, 2013.

4. Smart, A.; Jeranyama, P.; Owens, V. The Use of Turnips for Extending the Grazing Season; ExE2043; South Dakota State University Cooperative Extension: Brookings, SD, USA, 2004.

5. University of Georgia Weather Network. Past Data. University of Georgia. Available online: http://weather.uga.edu/?variable= HI\&site=WATUSDA (accessed on 18 August 2018).

6. Rao, C.S.; Horn, F.P. Planting season and harvest date effects on dry matter production and nutritional value of Brassica spp. In the southern great plains. Agron. J. 1986, 78, 327-333. [CrossRef]

7. Jung, A.G.; McClellan, W.L.; Byers, R.A.; Kocher, R.E.; Hoffman, L.D.; Donley, H.J. Conservation tillage for forage brassicas. J. Soil Water Conserv. 1983, 30, 227-230.

8. Kalmbacher, S.R.; Everett, P.H.; Martin, F.G.; Jung, G.A. The management of brassica for winter forage in the sub-tropics. Grass Forage Sci. 1982, 37, 219-225. [CrossRef]

9. Guillard, K.; Allinson, D. Yield and nutrient content of summer and fall-grown forage brassica crops. Can. J. Plant Sci. 1988, 68, 721-731. [CrossRef]

10. Wiedenhoeft, H.M.; Barton, B.A. Management and environment effects on brassica forage quality. Agron. J. 1994, 86, $227-232$. [CrossRef]

11. Jung, A.G.; Shaffer, J.A. Planting date and seeding rate effects on morphological development and yield of turnip. Crop Sci. Soc. Am. 1993, 33, 1329-1334. [CrossRef]

12. Westwood, T.C.; Mulcock, H. Nutritional Evaluation of Five Species of Forage Brassica; New Zealand Grassland Association: Dunedin, New Zealand, 2012; Volume 74, pp. 31-38.

13. National Academies of Sciences, Engineering, and Medicine. Nutrient Requirements of Beef Cattle (NRC), 8th ed.; The National Academies Press: Washington, DC, USA, 2016. [CrossRef] 